University of Wollongong

Research Online

Faculty of Law, Humanities and the Arts Papers (Archive)

Faculty of Arts, Social Sciences \& Humanities

$1-1-2014$

You had to be there: Anachronism and the limits of laughing at the Middle Ages

Louise D'Arcens

University of Wollongong, louised@uow.edu.au

Follow this and additional works at: https://ro.uow.edu.au/lhapapers

Part of the Arts and Humanities Commons, and the Law Commons

Research Online is the open access institutional repository for the University of Wollongong. For further information contact the UOW Library: research-pubs@uow.edu.au 


\title{
You had to be there: Anachronism and the limits of laughing at the Middle Ages
}

\begin{abstract}
Comic medievalism is one of the most widespread but least examined forms of postmedieval response. Its combination of comic modality, modern sensibility and historical vision captures what postmedieval audiences have deemed amusing about medieval society. But some instances have been less successful. 'You had to be there,' the phrase marking the failure of a comic attempt, and the relationship of that failure to the loss of immediacy, is realized in comic medievalism through the temporal fragility of laughter, historical mediation and temporal paradox. This essay explores some limitpoints to the comic reception of the Middle Ages, focusing especially on its use of anachronism.
\end{abstract}

\section{Keywords}

had, be, there, anachronism, limits, you, laughing, ages, middle

Disciplines

Arts and Humanities | Law

\section{Publication Details}

D'Arcens, L. (2014). You had to be there: Anachronism and the limits of laughing at the Middle Ages. Postmedieval: A Journal of Medieval Cultural Studies, 5 (2), 140-153. 


\title{
You Had to Be There: Anachronism and the Limits of Laughing at the Middle Ages Louise D'Arcens
}

English Literatures Program, University of Wollongong, Australia

\begin{abstract}
Comic medievalism is one of the most widespread but least examined forms of postmedieval response. Its combination of comic modality, modern sensibility, and historical vision captures what postmedieval audiences have deemed amusing about medieval society. But some instances have been less successful. 'You Had to Be There,' the phrase marking the failure of a comic attempt, and the relationship of that failure to the loss of immediacy, is realised in comic medievalism through the temporal fragility of laughter, historical mediation and temporal paradox. This essay explores some limit-points to the comic reception of the Middle Ages, focusing especially on its use of anachronism.
\end{abstract}

The phrase 'you had to be there,' uttered when recounting, or perhaps failing in the recount of, a joke or comic anecdote, marks the vulnerability of humor to a specifically spatiotemporal failure. It brings to light the extent to which humor depends for its success on its audience being 'present,' a word that reveals 'the inseparability of space and time' that Mikhael Bakhtin has famously called the chronotope (Bakhtin, 1981, 84) and in so doing figures pastness as a form of distance that makes jokes potentially inaccessible to latecomers. If you weren't there, the humor is lost to you, and any recount, despite striving to compensate for the loss of presence, can only reinforce it via further mediation. Even the frequent use of the present tense, which appears to narrow the temporal gap (a man generally walks into a bar, and so on), does not make the joke or humorous anecdote wholly present to us chronotopically, The scene in which the joke is set, according to Samuel Weber, is 
'impossible to locate because its "present" is not that of a representation, but of the process of representing "itself." This process produces a present that is, for its audience, tantalisingly 'both closer to us and more distant' (Weber, 1987, 706). In this essay, which is part of a larger project on comic representations of the Middle Ages, ${ }^{1}$ I will use a short meditation on the temporality of humor to consider its engagement with historical time, and in particular with the medieval past. Contemplating the ubiquitous but largely neglected phenomenon of historical humor, that is, humor that takes as its object historical events, cultures and peoples, I wish to explore the ways in which the temporal dimension of humor makes it an especially compelling vehicle for engaging with the past.

This is new terrain, both in humor studies and in medievalism studies. Although individual instances of comic medievalism have received scholarly attention, and Mikhail Bakhtin's theory of the carnivalesque has met with some probing reception, the specific valency of comic representations of the Middle Ages is yet to be theorized. Likewise, the temporal dimension of the comic experience has been a minority concern in humor studies, with only a small number of scholars engaging head-on with the question of how humor intersects with, and deploys, time. The question of comedy and time has generally been dealt with obliquely, either in discussions of the value of comic timing in performance, or, alternatively, in narratological analyses of how humorous texts, and jokes in particular, are constructed. These analyses are often structuralist in their approach, attempting to identify texts' conformity to cross-cultural narrative and discursive templates that elicit laughter. Such accounts are nevertheless useful to my discussion in that they implicitly invoke the concept of comic temporality in their examinations of how the diachronic unfolding of humorous narratives must create and exploit states of anticipation and expectation in audiences, states which they then subvert, frustrate, or fulfill. Some scholars of humor have used poststructuralist concepts such as Jacques Derrida's notion of différance to explain the 
movement of semantic deferral across the telling of the joke or the playing out of a comic scenario, and the anticipation built by this deferral (which either resolves or extends into a plane of jouissance), but the category of time is still generally secondary in these accounts to narrative structure. ${ }^{2}$ More avowedly philosophical analyses, however, engage directly with time as an indispensible condition of the phenomenological experience of humor. Mark C. Weeks, for instance, explicitly describes the diachronic building of expectation in comic narrative texts, and the anticipatory pleasure this produces, as 'an intensified experience of time' (Weeks, 2002, 391), a kind of enjoyable waiting.

The philosophical consideration of comic temporality becomes more complex, indeed paradoxical, when it takes into account the operation of laughter. Laughter is, of course, the response the humorous text solicits through its structuring of expectation; indeed, many would argue that the success or failure in eliciting (rather than just soliciting) laughter is what determines whether a text is humorous or not. Yet it is this very response that also ruptures the humorous text's temporal unfolding. In Immanuel Kant's famous formulation of laughter in The Critique of Judgement as 'an affection arising from a strained expectation suddenly reduced to nothing' (Kant, 1952, 199), the responding laugh marks the completion of the joke's narrative trajectory, and a release of the tension built across that trajectory. The paradoxical atemporality implicit in laughter's eruptive collapsing of narrative expectation -it all at once marks the joke's completion and the rupture of time into the pure present of humorous affect -- is not elaborated on by Kant; but it figures prominently in later philosophical engagements with laughter, especially Arthur Schopenhauer's discussion in The World as Will and Representation, which Weeks argues offers 'the most explicitly timebased theory of laughter' (Weeks, 2002, 392). Here Schopenhauer classifies the 'remarkable phenomenon' of humorous laughter (which he distinguishes from, on the one hand, involuntary laughing from being tickled and, on the other, from the sardonic laughter of 
failed expectation) as a species of what he calls perception, which he defines as an 'original,' instinctual knowledge which is 'the medium of the present, of enjoyment and gaiety ... in which everything that gives direct satisfaction to the will presents itself' (Schopenhauer, 1989, 280). Perception is distinct from, and has the power via laughter to override, conception, the reflective, rational habit of thought which is grounded in a recognition of temporality, of past and future, and is invested in the deferral of satisfaction. Although Schopenhauer describes conception as 'the medium of seriousness' (Schopenhauer, 1989, 280), it can be argued that comic narrative's reliance on temporal framing, anticipation, and deferral also brings it under the rubric of conception, and thus at risk of being simultaneously fulfilled and breached by the explosion of untimely, present-immersed laughter. In Schopenhauer's formulation, laughter is outside of time and discloses the paradoxical temporality of the successful comic text, where the laughing subject both enjoys the temporal momentum of the joke and takes pleasure in arresting that momentum.

This emphasis on the dominance of the 'now' in laughter does partly collude with the tendency in humor studies to dwell almost exclusively on humor's engagement with the present. Sociologists of humor have, for instance, been occupied with the ethical stakes of laughing at social minorities, and with the forms of social exclusion reinforced, and indeed performed, by such humor. An increased sensitivity to humor as an instrument either of social tolerance or of bigotry has gained momentum in response to globalization's and multiculturalism's drawing of different ethnic, cultural, and religious communities into daily proximity with one another (see, for example, Billig, 2005). Because of its presentist ideological commitments, this scholarship addresses itself virtually exclusively to analysing the role of humor in establishing relationships, and especially hierarchies, between contemporaneous or cohabiting groups. Historical humor, by contrast, has attracted little attention because there is no possibility of cohabitation between the subject and object of the 
humor, and hence perceived to have little ethical urgency. Nevertheless, I wish to suggest that Schopenhauer's and Weeks's acknowledgements of humor's paradoxical temporality, dwelling both within and outside of time, are pivotal to a consideration of historical humor. What they reveal is that at its very heart, laughter is an anachronistic phenomenon, in which the pleasurable 'now' intrudes into the serious engagement with chronology.

This is significant because this fusion of the 'now' with the 'then' is the same temporal dynamic that dominates comic medievalism as a cultural practice, manifesting as comic anachronism. The liberal use of anachronism is a much-noted but still under-theorized dimension of medievalism, which is now beginning to be more rigorously examined, as in Tison Pugh and Angela Weisl's recent discussion of its use in cinema (Pugh and Weisl, 2013, 84-98). Anachronism can be seen to function as the historically-inflected form of what humor theorists have for some time, in the wake of Schopenhauer's formulation of Inkongruenz (Schopenhauer, 1989, 59), described as 'incongruity humor,' which, as its name suggests, generates laughter via dissonance and the surprising conjunction of unlikely components. ${ }^{3}$ Comic anachronism is arguably constitutive of a significant proportion of historical humor and has been used in comic representations of the past ranging from the 'swinging sixties'-style classical period lampooned by screenwriter Talbott Rothwell in Carry On Cleo (1964) through to, and beyond, the clear Vietnam-era allusions of $M * A * S * H$, the hugely popular satire of the Korean War (film1970, television series 1972-83). Despite its general applicability across the gamut of historical comedy, anachronism has, I suggest, particular relevance for medievalism, coalescing with numerous scholarly arguments that the stubborn, asynchronous persistence of the abjected medieval past within modernity queries the ideological stakes of linear and progressivist conceptions of time and suggests the value of conceptualizing history as a realm of co-temporality. Observations about how medievalist 
texts and practices collapse premodern and modern time frames into a single moment can readily be extended to describe a burst of anachronistic medievalist laughter.

Medievalist comic anachronism is a form of incongruity humor in that it solicits amusement through the wilful and playful introduction of incongruous modern elements into medieval scenes, or else, in the case of reverse time-travel comedies such as Stephen Herek's Bill and Ted's Excellent Adventure (1989) and Jean-Marie Poiré's Les Visiteurs (1993), through the madcap intrusion of medieval elements into modern scenes. Arguably the most influential theorization of anachronism, which has also been examined recently by Pugh and Weisl vis-à-vis medievalist texts, is Thomas M. Greene's five-fold taxonomy in The Vulnerable Text. Of Greene's five categories, comprising naive, abusive, serendipitous, creative, and tragic anachronisms, the one most readily identifiable within comic medievalism appears to be his fourth, 'creative anachronism.' While the other forms, according to Greene, 'stem . . . from ignorance or repressing or felicitously misunderstanding the nature of change,' creative anachronism is distinguished by a deliberate use of incongruity which 'bring[s] a concrete present into relation with a specific past and play[s] with the distance between them' (Greene, 1986, 220-222). The intentionally ludic nature of this anachronism makes it especially apposite for comic usage. Yet even Greene's creative anachronism requires some adjustment for application in relation to comic medievalism, for while he argues that creative anachronism 'involves a deliberate dramatization of historical passage,' I will go on to show that comic medievalism both dramatizes history's 'diachronic passage' and pleats it into synchrony, simultaneity, and a paradoxical temporality.

Further, the starkness of Greene's distinction between playful and ignorant anachronism is unsettled somewhat by Pugh and Weisl's analysis of films such as Gil Junger's film Black Knight (2001), which, they argue, not only 'flourishes' as a result of its reliance on naive anachronism, but is far more sophisticated than it seems (Pugh and Weisl, 
2013, page). Although comedy is not their focus, their account accords with mine in showing that comic medievalism is particularly well-placed to make nuanced and knowing use of temporal disjunctions and incongruities. This scholarly perspective is, moreover, reinforced by commentaries within popular culture. One especially amusing commentary on the pleasures of medievalist anachronism can be found in 'The Codpiece Topology,' an episode of season two of the CBS sitcom The Big Bang Theory. The episode opens with a scene in which the pathologically rigid and pedantic character Sheldon Cooper storms into his building having just returned, affronted, from a Renaissance Fair. Complaining that the event was a 'medieval-slash-Age of Enlightenment-slash-any excuse to wear a codpiece fair' he condemns it for being 'rife with inaccuracies' that include incorrect costumes, its failure to observe the fifteenth-century Reinheitsgebot (German beer purity laws), and its use of polypropylene flagons. Despite the attempt of his less 'nit-picking' friend Howard to explain that 'Renaissance fairs aren't about historical accuracy,' Sheldon can't be budged from his incensed conviction that "you can't just put "Ye Olde" in front of anything you want and expect to get away with it.' For all its brevity, this scene points deftly to the stakes involved in accepting or rejecting anachronistic comic medievalism. By having the famously humorless Sheldon, whose literalism is usually directed at scientific subjects, condemn anachronism for its 'inaccuracies' on the assumption that they emerge solely from blithe ignorance, the programme is able implicitly to take the side of creative anachronism, exposing people's readiness to embrace historical pedantry but the misguidedness of this in situations that are soliciting anachronistic laughter. The fact that Howard defends the inaccuracies of the fairs while dressed in a jester's motley, while Sheldon is dressed in monastic garb, visually aligns the embrace of anachronism with comic performance, and the dismissal of anachronism with a dogmatic culture that fails to recognize the ironic and playful ways in which the past can be put to use. 
As a comic technique, anachronism can take a range of forms. One form produces a Middle Ages that fosters in members of post-medieval cultures a comic identification with the period, tracing transhistoric lines of cultural continuity. A much-loved instance of this is British comedian Bill Bailey's stand-up routine 'Pubbe Gagge,' as seen on the recording of his 2001 Bewilderness tour. This ingenious forty-four line comic tale of a drunken lads'night-out is narrated mostly in decasyllabic rhyming couplets with heavy comic emphasis on the final -e, 'in the style of Geoffrey Chaucer':

Three fellows wenten into a pubbe

And gleefullye their handes did rubbe

In expectation of revelrie

For 'twas the hour that is called happye ...

Notwithstanding its use of the past tense, which in any case is used because it allows Bailey to avail himself of such archaisms as 'did rubbe,' this performance presents the pub gag as a beloved local genre spanning six centuries, linking Chaucer to Bailey via the Dick Emery Show of the 1970s. By later including a reference to the 'lewdness and debaucherie' of Emery's very politically-incorrect sketches, Bailey cheekily suggests that they contribute, like his and Chaucer's tales, to a continuous comic tradition portraying a long-thriving ritual of British life. Bailey does not present himself simply as an heir of Chaucerian bawdy, but rather as telling a 'very old pub joke' that is simultaneously -- or as Linda Hutcheon would say, palimpsestuously -- both his and Chaucer's inheritance and creation (Hutcheon, 2012, 21). This is reinforced by the gag's cross-historical idiom (epitomised by the amusingly bathetic 'after wine and meade and sack / man muste have a massive snack') and by the relish Bailey takes in his mock-Middle English delivery. 
The performative dimension of this is vital; as theatre historians have pointed out, the referential nature of the live performing body has been vital to grounding genres such as Victorian historical burlesque in the present, even when this body is dressed in meticulous period costume (Schoch, 1998, esp. 10-12, 116). Bailey's skit explicitly evokes, moreover, a paradoxical temporality: having described the tale as 'like a sketch by Dick Emery,' BaileyChaucer goes on to say 'Except that Dick Emery is not yet born / So such a comparisonne may not be drawn,' an utterance that confounds audiences with its baffling multi-temporality, which, in turn, provokes the skit's biggest eruption of laughter: a perfect fusion of anachronistic humor and atemporal laughter. To cite Zachary S. Schiffman's recent addition to Greene's taxonomy, Bailey's gag, along with so many other comic medievalist texts, exhibits an 'awareness of anachronism as "error," but embraces the comic potential of this error to bring about a 'synchronic encounter' of the medieval past and the present that teases us out of (historical) thought and into laughter (Schiffman, 2011, 146).

Another kind of anachronism inverts the temporal confusion produced by Bailey; rather than medievalizing the present, it endows the Middle Ages with a particular set of 'modern' qualities. One hugely popular illustration of this is the 'Medieval Helpdesk' skit from a 2000 episode of the Norwegian television show Øystein og jeg. In this skit a medieval 'tech guy,' with typical cheery perfunctoriness, coaches a bamboozled monk, Brother Ansgar, through the shift from parchment rolls to bound books. A favorite with medievalists, this densely clever skit has also enjoyed viral popularity as a YouTube clip. Interpreted superficially, this skit would appear to be ridiculing the rudimentary nature of medieval 'information technologies' as well as the era's perceived hostility to innovation, where an object like the humble book could be incomprehensible and threatening. But its ingenious transposition of the dynamics of the familiar modern 'helpdesk' exchange onto an earlier watershed in the history of literacy, showing medieval people speaking in a barely altered 
modern script, elevates it to the realm of double-visioned satire, addressing itself via the Middle Ages to the sense of disorienting inevitability that surrounds today's culture of accelerated change in information technologies. While its humor appeals partly to modern viewers' sense of having progressed beyond the Middle Ages, cheekily likening those who fail to keep up to the progress-averse Ansgar, its use of familiarizing situational comedy invites the sympathetic laughter of identification with the hapless monk's struggle to absorb the shock of the new. What this skit also shows is that comic medievalist texts are frequently satiric, calling attention, via the medieval, to the many unexamined contradictions underpinning the values of modernity, and providing Western culture with an historical mirror in which it can reflect on and even reform itself. Their apt yet uneasy fusion of critical intent, comic modality, and historical content makes it a complex phenomenon that simultaneously ridicules and valorizes the medieval vis-à-vis modernity in a prankish game of rejection and reclamation.

Given anachronism is intrinsic to the act of laughter itself, it might appear to be a failsafe formula for historical humor; but in fact its untimeliness must be finely calibrated so that the use of anachronism facilitates both the comic intent of the text and its historicist commentary, as well as any contemporary commentary it might attempt. One example of a comic text that does not quite strike the right balance, as I will now discuss, is the first series of the BBC television program Blackadder.

Blackadder is of particular interest when considering comic medievalism for two reasons. The first is that it has four series set in four different historical periods, tracing the (usually foiled) exploits of its bumbling protagonist Edmund Blackadder (played by Rowan Atkinson) across four centuries and more. This transhistorical span allows for comparison of how these eras are represented, and thus what is specific in its treatment of the Middle Ages. The second reason is that its first series, which is set in and just after 1485, beginning with a 
radically re-imagined Battle of Bosworth Field (Richard III survives the battle only to be decapitated accidentally, while urinating, by Edmund, whose father is then crowned Richard IV), is widely regarded as less funny than the subsequent series. ${ }^{4}$ It is worth investigating what it is exactly about the first series' medievalism, and in particular its deployment of creative anachronism, that has limited its success in moving audiences to laughter.

Though the program is well-known, I will sketch its series-by-series trajectory. The central character Edmund Blackadder in each series is a descendant of the previous series' Edmund Blackadder (despite none of the Edmunds ever siring, or having any prospect of siring, any children). In each respective series, Edmund experiences a decline in social status but a concurrent rise in intellect, going from being a medieval royal moron (Series One) to being a droll Elizabethan courtier (Series Two), the sardonic butler to George the Prince Regent (Series Three), and eventually a dry-witted army Captain in World War I (Series Four). In sum, he evolves from being a high-born joke to a low-born satirist. Edmund's fortunes are inexplicably, but also inextricably, tied to that of his manservant, Baldrick, played by Tony Robinson, whose destiny remains fairly constant in that he is at the bottom of the social hierarchy in all series, but he goes from being in Series One a clever character who exposes the arrogance of power, to a lovable idiot in the later series who does not question his inferiority to his masters or their mandate to rule. Despite having a cult status as a comic text, the series is equally famous for its tragic and moving conclusion in Series Four, Blackadder Goes Forth, set in the trenches of the Somme.

One distinctive characteristic of the first series is its overall dependence on an unsympathetic portrayal of the Middle Ages. In his study Redeeming Laughter, humor theorist Peter Berger argues that comic texts commonly require audiences to think and respond in an affectively complex way, simultaneously objectifying yet sympathizing with characters and situations (Berger, 1997); and indeed, this is true of the best medievalist 
comedy, which has a double nature that enables audiences to engage in an atemporal laughter through which they both ridicule and sympathize with premodern characters. But this is not the case with Blackadder's comic medievalism, which for the most part only laughs at the Middle Ages. This ridicule of the period rests largely on portraying it as intellectually, culturally, and socially stagnant. This is not evident just in the first series, but in the way the Middle Ages is alluded to in the later series. In the opening scene of 'Head,' episode 2 of Series Two, the period is aligned with ignorance, as the now-Elizabethan Edmund attempts to teach Baldrick how to count. When Baldrick proves unable to get past three, despite the fact that 'the ape creatures of the Indus have mastered this,' Edmund regards him coolly and says 'the Renaissance is something that happened to other people, isn't it?' Here the figure of Baldrick, who has now been transformed from a clever squire to a dim-witted dogsbody, is aligned not only with premodernity but with the simian stage of human evolution, a collocation repeated throughout the final three series of the program. The motifs most commonly associated with Baldrick right up to the final series are turnips and rats, which become metonymic of his continued connection to premodernity. Even as late as Series Four, the medieval is invoked as the historical apotheosis of idiocy, when Edmund says 'A war hasn't been fought this badly since Olaf the Hairy, high chief of all the Vikings, accidentally ordered 80,000 battle helmets with the horns on the inside.' The gross incompetence of WWI military rule is only outstripped by the stupidity of medieval warfare, with the Vikings -horned, as custom dictates -- invoked as the epitome of inane medieval barbarity. All of this reinforces the anti-medieval view to which the program commits itself.

Central to the first series' portrayal of (an admittedly fictional) late medieval England is the notion of social rigidity. While the program's later periods are presented as in a state of social flux, with the emergent urban middle classes increasingly asserting their presence, this is not evident in the English late Middle Ages of the first series, which, despite opening with 
the Wars of the Roses and upheaval in the wake of Richard III's death, are presented as feudal, hierarchical, and static. Given the English fifteenth century was in fact characterized by relative social mobility, religious dissent, and early capitalism, this emphasis on feudal stasis is questionable; but it is vital to the program's representation of the Middle Ages as risible. The almost exclusively monarchical focus, which reflects the legacy of Shakespeare's chronicle plays (Shakespeare is credited as a co-writer in this series), buttresses the show's preoccupation with rigid hierarchy and presents modern audiences with a top-down image of a world gone mad with power struggles, scheming, and paranoia over succession.

This deliberately under-nuanced representation of the Middle Ages can be better understood when one takes into account contemporary political events and issues under debate in the UK at the time it was being written and produced. To begin with, the program's satire of the medieval institution of monarchy can be read in part as a response to the renewed interest in royal succession in the early 1980s as a result of the marriage of Prince Charles to Lady Diana Spencer in 1981, and the birth of their heir Prince William in 1982. Antimonarchists and those on the Left in Britain were dismayed at the 'royal fever' that accompanied Charles's betrothal and marriage to Diana. The programme that channelled antimonarchism most conspicuously was ITV's satirical puppet show Spitting Image, which ran from 1984-1996 and on which Richard Curtis and Ben Elton, an outspoken critic of the Royal Family, were both writers at the same time as they were developing the scripts for Blackadder One and Two; so Blackadder can, I argue, be seen as entering into dialogue with this broader critical movement. The stupidity, arrogance, and undeserved privilege of royalty is a running theme in the first three series of Blackadder, with Richard IV, Elizabeth I ('Queenie'), and George the Prince Regent together tracing an unbroken cross-temporal line of undeserved power. But in the first series, this is particularly pointed by having Edmund as an actual member of the family. Analysing the series' use of anachronism in terms of 
contemporary British politics, it is significant that he is called the Duke of Edinburgh, a title that was not in fact introduced into the British peerage until 1726. The representation of the monarchy in Blackadder not only uses the time-honored satiric technique of anachronistically displacing social critique onto another period in history, but by beginning with the medieval period in particular, it makes the point about the outmoded, pre-democratic nature of the institution. As will become apparent, however, the series nurses a residual ambivalence which undermines its satiric potential. Richard Curtis and Rowan Atkinson have been less determined to overtly politicize their work than their Blackadder collaborator Ben Elton, so caution must be exercised in tethering the show to their more benign (for the time) attitude to the monarchy. Nevertheless, it is intriguing to speculate as to whether their divided ideological commitments did ultimately contribute to the limitations I will go on to explore.

Series One's lampooning of hereditary rule also engages with the outcry on the British Left at the steady rejuvenation of the role of the House of Lords in British politics since the election of Margaret Thatcher's Tory government in 1979. In fact, only four days before the inaugural screening of The Blackadder in 1983, Thatcher conferred the first hereditary peerage in almost twenty years, following it with a second exactly a month after the first screening. This conferral of unelected parliamentary power was vigorously opposed as 'undemocratic' by the Labour opposition, who vowed that they would abolish the Upper House on their return to power. In Blackadder Series One, the medieval period becomes synonymous with the arbitrary conferral of unelected power.

On a different tack, the program's satire of the arbitrariness of privilege also reflects the writers' critical stance on the neo-liberal policies of the Thatcher government. These series were produced against a now-legendary background of social unrest, characterized by major strikes, economic deregulation, high unemployment, the Falklands war, and welfare cuts. ${ }^{5}$ Many prominent British entertainers throughout the 1980s, including the Red Wedge 
(Billy Bragg, Paul Weller, The Smiths, and others) and Blackadder's writers, used their art as activism against these conditions (see Frith and Street, 1992, 67-80). Again, this series can be seen as a kind of historical counterpart to such shows as Spitting Image, whose most frequent target was Prime Minister Thatcher, and to the satirical news magazine Private Eye. This theme is more subtly dealt with as the program continues; in Series Two and Three, Edmund's constant opportunistic attempts to better his conditions are constantly and tragicomically thwarted, exposing the meritocratic mythologies of Thatcherite class aspirationalism. Additionally, Series One's portrayal of belligerence, vapidity, greed, and xenophobia as the foundational characteristics of the English national tradition is arguably the most pointed of all the series in offering an ironic stance on the discourse of 'stemming the national decline from greatness' used by the Thatcher government as its platform for brutal economic and industrial reforms (Hall, 1988, 49; Letwin, 1992, 277-306).

Considering Edmund's character in light of the larger question of anachronism and its potential pitfalls as a satiric device, his social position in Series One presents a problem. Numerous people involved in the creation of the show, including Rowan Atkinson himself, have retrospectively identified a lack of satiric definition with the first series' representation of Edmund as a medieval character, which in turn affects his ability to elicit laughter from audiences. ${ }^{6}$ Although Atkinson is not concerned centrally with Edmund's transhistorical valency, it is arguably a key problem with the character. The medieval series is distinct in that unlike the later series, where Edmund is vulnerable to the whims of autocrats because of his lower rank, in Series One he is of royal rank, and is only thwarted because of his own stupidity. Numerous humor theorists, as mentioned earlier, have discussed the vital role of incongruous elements in generating satiric humor, as the unexpected juxtaposing of these elements exposes society's received structures and assumptions. Making Edmund a member of the royal family, albeit a reviled one, diminishes his satiric potential because he is not 
sufficiently socially marginal or incongruous to offer critique. He cannot critique power from below, as his marginalized status as despised second son of King Richard IV is a result of his idiocy, not his social disenfranchisement. He doesn't query power; he is simply too stupid to seize it, despite repeated attempts. This structural problem is rectified in his characterization in later series, where he becomes, respectively, a member of the gentry, 'middle' classes, and lower classes, and hence able to engage in social critique from below and sometimes from above. This frees him to evolve into a historically incongruous character and a witty, verbally-driven commentator on folly. The overt alignment of him with a culture of metropolitan wit in these series establishes him as a 'hinge' character who is simultaneously of his time and modern, and so both an object of comedy and a kind of anachronistic proxy for the viewpoint of twentieth- and twenty-first-century viewing audiences; but this is unavailable to him the first series. In short, the medieval Edmund is not anachronistic enough to the program's historical milieu to act as a focalizing character for the program's medievalist satire of monarchy, or to attract sympathetic, atemporal laughter from modern audiences. This structural problem is carried over into Atkinson's performative characterization. The farcical nature of his performance, which relies on proto-Mr Bean-like exaggerated physical comedy and on ludicrous costuming, including monstrous codpieces and a pudding-basin haircut, renders the medieval Edmund too cartoonishly 'medieval' to operate as the subject rather than the object of the show's satire.

The series' unstable realisation of anachronism is also visible in the first series' physical setting. Shot on location at Alnwick Castle and Brinkburn Priory, both grand Norman structures in Northumberland, it is, like Edmund, 'thoroughly medieval'; and again this ultimately works to compromise its comic potential. Part of the rationale behind the selection of these sets was that the series' co-writers Atkinson and Curtis were anxious for the program not to languish in the long shadow cast by the hugely successful 1970s BBC 
comedy series Fawlty Towers, so they opted for a large historical canvas over the latter's more restricted set. Apart from the fact that the shooting for the first series became prohibitively expensive, it also situates this series in a 'real' Middle Ages which, while lending atmosphere and authenticity, has two undesired effects. First, it mixes generic visual codes, signifying historical drama (a danger already courted by basing itself on Shakespeare's chronicle plays) instead of the more broadly-drawn historicism of TV comedy. As epitomized in the grand exterior shots of Alnwick Castle in the series' opening credits, this uneven approach to anachronism suggests an ambivalence that sits somewhat at odds with the otherwise ludicrous portrait of the Middle Ages, offering a loving aesthetic representation of the period being lampooned. Secondly it reinforces or even increases the historical distance between the past and the present of the viewing audience, placing the characters firmly in a medieval milieu in a way that diminishes the historical parallelism that is fundamental to its satiric critique. The elusive 'there' of the joke as chronotope is not in this case simply, to revisit Weber's formulation, 'closer to us and more distant,' but, even more paradoxically, becomes historically remote from us because it is so present spatially in all its medieval difference from the modern. From Series Two onward location shooting was replaced by a small studio set comprising only Edmund's quarters plus one or two other spaces -- in other words, a 'drawing-room comedy' set of similar scope to Fawlty Towers. Along with the problem of historical distantiation created by the location set, from a technical point of view location shooting also precluded the use of a studio audience and the intimacy of that format, which in turn prevented the performers and writers from gauging whether the series was actually funny. Notwithstanding the relative modesty of these later sets, the greater physical and historical proximity with the audience in the later series proved a more successful comic formula. 
It is this uncertain commitment to anachronism that prevents audiences from engaging in wholehearted anachronistic laughter. Furthermore, its ultimate investment in the supersession of the medieval by the modern muddies its exposure of the untimely survival of the medieval in the modern. Judging from early reviews, it seems that the show's muddled execution attracted more attention than its satiric content. This contrasts with the reception of the later series and, especially, with the universal recognition of the powerful anti-war satire in Series Four, Blackadder Goes Forth. Perhaps it is most accurate to think of the program as having made an oblique and ambivalent contribution to the larger culture of protestentertainment throughout the Thatcher government's term of office. Certainly some curious recent historical ironies in the afterlife of Blackadder suggest that the anti-monarchist message did not stick. In 2002 Rowan Atkinson was asked by Buckingham Palace to make a one-minute commercial garnering public interest in the Queen's golden jubilee, which he performed in the persona of 'Sir Osmond Darling-Blackadder, Keeper of the Queen's Lawn Sprinklers.' (Blackadder 2002). Whether this was the Royal family's attempt to neutralize critique through self-irony is not entirely clear, but it is suggested by the fact that in 2011 Prince William and his then-fiancée Kate Middleton actually commissioned a portrait of Edmund and Queenie from Series Two to hang on the wall of the bride's prenuptial suite (Larcombe, Sales, and Syson). The crowning irony is the fact that these very nuptials (which Atkinson, now a good friend of Prince Charles's, attended) ${ }^{7}$ and, more recently, the birth of the couple's son Prince George prompted a royal frenzy on a scale not seen since the marriage of William's parents, when the first Blackadder was being conceived. The eventual depoliticizing of the program across its longer reception points to the double-edged sword of historical humor -- its capacity to reify historical progression. In its richest iterations, however, the atemporality of laughter dovetails perfectly with anachronistic content, so that 
when laughing at the Middle Ages, we also laugh at ourselves, and at the recursive loopiness of time itself.

\section{About the Author}

Louise D'Arcens is the author of Old Songs in the Timeless Land: Medievalism in Australian Literature, 1840-1910 (Brepols/UWAP, 2011/12) and Laughing at the Middle Ages: Comic Medievalism (Boydell and Brewer, forthcoming 2014). She co-edited International Medievalism and Popular Culture (Cambria, forthcoming 2013) and Maistresse of My Wit: Medieval Women, Modern Scholars (Brepols, 2004). She is an Australian Research Council Future Fellow, and teaches in the English Literatures Program, University of Wollongong, Australia (E-mail: louised@uow.edu.au).

\section{Notes}

1. See Louise D'Arcens, Laughing at the Middle Ages: Comic Medievalism (Boydell and Brewer, forthcoming 2014). The project 'Comic Medievalism and the Modern World' is supported by the Australian Research Council (FT120100931).

2. See Mark C. Weeks (2005, 131-148).

3. On Schopenhauer's development of an embryonic theory of comic incongruity, see Peter Lewis (2005).

4. For a detailed documentation of the perceived strengths and weaknesses of Series One, see F. J. Roberts (2012, 68-130).

5. For a comprehensive and close-up account of the British left's response to Thatcherism, see Stuart Hall (1988).

6. Blackadder Rides Again (2008), in Blackadder: Complete Collection Remastered. 
7. Roberts $(2012,369)$ in fact medievalizes Atkinson's relationship with Prince Charles by placing it within a long English history of 'Humour by Royal Appointment' stretching back to Henry II and Roland the Farter.

\section{References}

Bailey, B. 2001. Pubbe Gagge. Bewilderness. Talent Television.

Bakhtin, M. 1981. The Dialogic Imagination: Four Essays, trans. C. Emerson and M. Holquist. Austin, TX: University of Texas Press.

Berger, P L. 1997. Redeeming Laughter: The Comic Dimension of Human Experience. New York: Walter de Gruyter.

Billig, M. 2005. Laughter and Ridicule: Toward a Social Critique of Humour. London: Sage. Blackadder. 2012. Complete Collection Remastered, BBC and Tiger Aspect.

Blackadder 2002: The Queen's Jubilee. http://www.youtube.com/watch?v=h8PZkpPtsFw. de Groot, J. 2009. Consuming History: Historians and Heritage in Contemporary Popular Culture. New York: Routledge.

Frith, S., and J. Street. 1992. Rock Against Racism and Red Wedge: From Music to Politics, from Politics to Music. In Rockin’ the Boat: Mass Music and Mass Movements, ed. R. Garofalo, 67-80. Boston, MA: South End Press.

Greene, T. M. 1986. The Vulnerable Text: Essays in Renaissance Literature. New York: Columbia University Press.

Hall, S. 1988. The Hard Road to Renewal: Thatcherism and the Crisis of the Left. New York: Verso.

Hutcheon, Linda. 2012. A Theory of Adaptation. 2nd ed. Oxon, UK: Routledge. Kant, Immanuel. 1952. The Critique of Judgement, trans. J. C. Meredith. Oxford, UK: Clarendon Press. 
Larcombe, D., D. Sales, and N. Syson. 2011. Royal Suite where Kate Middleton will stay before she weds Prince William. The Sun, 20 April.

http://www.thesun.co.uk/sol/homepage/news/royalwedding/3528441/Royal-suitewhere-Kate-Middleton-will-stay-before-she-weds-Prince-William-See-photos.html.

Letwin, S. R. 1992. The Anatomy of Thatcherism. New Brunswick, NJ: Transaction Publishers.

Lewis, P. B. 2005. Schopenhauer's Laughter. The Monist 88(1): 36-51

Medieval Helpdesk. http://www.youtube.com/watch?v=pQHX-SjgQvQ.

Pugh, T., and A. J. Weisl. 2013. Medievalisms: Making the Past in the Present. New York: Routledge.

Roberts, F. J. 2012. The True History of the Black Adder. London: Preface Publishing.

Schiffman, Z. S. 2011. The Birth of the Past. Baltimore, MD: Johns Hopkins University Press.

Schoch, R. 1998. Shakespeare's Victorian Stage: Performing History in the Theatre of Charles Kean. Cambridge, UK: Cambridge University Press.

Schopenhauer, A. 1989. The World as Will and Representation, trans. E. F. J. Payne. New York: Dover Publications.

Weber, S. 1987. Laughing in the Meantime. MLN 102(4): 691-706

Weeks, M. C. 2005. Milan Kundera: A Modern History of Humor amid the Comedy of History. Journal of Modern Literature 28(3): 131-148.

Weeks, M. C. 2002. Laughter, Desire, and Time. Humor 15(4): 383-400. 